\title{
Student-to-Student Interactions in Marketing Education: A Critical Incident Technique- based Inquiry into Drivers of Students' (Dis)Satisfaction
}

\begin{abstract}
Business schools are increasingly concerned about retaining and recruiting new students. We examine interactions among marketing students to consider their consequences on student satisfaction. This paper's objective is to determine the drivers of satisfactory and dissatisfactory student-to-student interactions by employing a critical incident technique. In doing so, this study identifies three groups (group assignments, peer relations, and outcomes) and eleven categories of satisfiers and dissatisfiers. The study's findings advance the understanding of the impact of students-to-student interactions on student satisfaction and illustrate the importance of the management of these interactions in the context of marketing education.
\end{abstract}

Keywords: student-to-student interactions, student peer interactions, marketing education, business school, student experience, student satisfaction, critical incident technique 


\section{Introduction}

Increasing globalization has led to a highly competitive international higher education market, driven by increased competition, decreased government funding, and the increased cost of education (Jabbar et al., 2018). At the same time, as a result of marketization (John \& Fanghanel, 2016; Vos \& Page, 2019), higher education institutions (HEIs) are increasingly identifying as a service industry and have begun operating like traditional service firms (Gruber et al., 2012). Therefore, student (i.e., customer) experience has emerged as an important competitive factor for higher education service providers, such as business schools (Bunce et al., 2017; Tan et al., 2016; Temple et al., 2014). The student experience has become a critical selling point for higher education institutions in attracting suitable applicants who likely have many program options (Morgan, 2013), as well as a key strategic variable in maintaining a competitive position. Long-term benefits resulting from a focus on the student experience include student loyalty, positive word-of-mouth, and an improved image of the higher education institution (Arambewela et al., 2006). The quality of the student experience can determine the reputation and long-term survival of a business school in an increasingly competitive marketplace for higher education (Staddon \& Standish, 2012).

Due to the marketization of higher education, specifically the operation of business schools as higher education service providers, we draw upon extant service marketing/management literature to inform our empirical inquiry. Although there is some resistance to the concept of treating students as customers in higher education (HE; Searcy, 2017), we consider students to be the primary customers of HEIs (Guilbault, 2016), even in countries where they do not have to pay tuition fees (Douglas, Douglas \& Barnes, 2006). 
Therefore, we build upon existing work on customer-to-customer interactions and apply it to a marketing education context. We define marketing education as the student experiences related to the peer interactions that occur in HEIs' marketing programs. This definition aligns with two main topical categories of marketing education: student assessment and course management (Gray et al., 2012).

Classroom-based, student-to-student interactions are a key part of marketing students' experiences at their institutions (Temple et al., 2014). Drawing on a substantial body of literature representing students' views (Canning, 2017; Tomlinson, 2017), we argue that it is essential for marketing educators and higher education managers to understand student-tostudent interactions to identify drivers of student (dis)satisfaction. In doing so, business schools can better manage marketing students' experiences to benefit their institutions. We believe that there is a need for more research on classroom encounters in marketing education, and our study aims to make such a contribution. This study is the first to address this important gap within the current body of literature.

The term student experience appears in a variety of contexts, and it is connected with both policy and practice in several different countries (Jones, 2018). In terms of the service setting, student experiences can encapsulate both off-site and on-site experiences (Harris et al., 2000). As marketing students' experiences are multidimensional, we limit the application of this concept to the key aspects of classroom-based (i.e., on-site), student-to-student interactions, with a limited focus on in-class (i.e., in-the-classroom) interactions. Our study encompasses the interactions between marketing students, as well as between marketing students and students from business and management programs with a marketing component. The study includes both undergraduate and postgraduate students. 
Our research has a specific regional context, focusing on students from the United Kingdom (UK) and Poland. American higher education literature has asserted that the assessment of student satisfaction is not only appropriate but "necessary due to pressures from decreasing enrollment, budget cuts, shrinking fiscal resources, and increased competition for government funding and private support" (Herdlein \& Zurner, 2015, p. 2). In Europe, there has been significant change since 2004, when Bateson \& Taylor (2004) found that university decision makers only received sporadic student feedback. In the UK and Poland, evaluations of student experience and satisfaction are a common and an integral part of government higher education assessments. In the UK, the annual National Student Survey (NSS) is not only one of the many criteria that contributes to the university league table positions, but it is also an important component of the Teaching Excellence and Student Outcomes Framework (TEF), which is the government system employed to assess the quality of teaching in universities. In Poland, student satisfaction is also becoming an important factor of higher education quality assurance, despite the lack of fees for students of higher education. Polish universities are a part of the European Higher Education Area created by the Bologna Declaration, which standardized degree programs and enabled mutual recognition of degrees earned at universities within the area. Consequently, this standardization has facilitated a high level of student mobility and a resulting advance in quality assurance among HEIs. Correspondingly, European HEI managers, in addition to focusing on classroom learning, are realizing the importance of assessing students' satisfaction and that the retention of existing students is just as important as enrolling new students (Herdlein \& Zurner, 2015).

This paper is divided into three sections. First, we discuss the theoretical background of student experience and classroom-based, student-to-student interactions, as well as their relevance for marketing education. Second, we describe the methodology of our research and 
present the study's findings. We conclude by outlining the study's theoretical contributions, practical implications, and future research directions.

\section{Theory}

\section{Student experience}

It is essential that marketing educators and business school managers understand the elements that influence the educational experiences of their students. Before we define student experience, we briefly describe its underlying concept, which is the customer experience. Customer experience has become a key focus of both contemporary service research and management practice (Friman et al., 2015). Creating a meaningful customer experience is pivotal for achieving satisfied customers and gaining a competitive advantage (Bolton et al., 2014). Customer experiences are not solely derived from organizations' efforts (Friman et al., 2015); they also stem from customers' interactions with other customers (Lemon \& Verhoef, 2016). Consequently, there has been a move away from a dyadic, firm-to-customer perspective to a broader view that includes multiple customers.

We posit that a similar relationship exists in the context of marketing students' experiences and student-to-student interactions. There is no general agreement on how to define student experience. The term appears in a variety of contexts connected with educational policy and practice in several different countries (Jones, 2018). Some contexts attach greater significance to students' academic experiences and the quality of the educational service (Sultan \& Yin Wong, 2013), including: opportunities for student engagement (Jones, 2018), contact with the faculty (DeShields et al., 2005), and classroom experiences (Stodnick \& Rogers, 2008). However, other contexts define the concept more broadly to include the totality of a student's interaction with the institution (Gibson, 2010). Drawing on the most widespread definition (Benckendorff et al., 2009; Douglas, McClelland, \& Davies, 2008) and adjusting it to our context, we define student experience as the nature of 
student engagement with classroom-based marketing education teaching, learning, and assessment, as well as exposure to other HEI ancillary service aspects in the classroom. Moreover, Tan et al. (2016) identifies five dominant research streams that focus on the quality of the student experience: exploration of learning experience, exploration of student experience, gender differences in assessment of higher education experience, improvement in quality of student experience, and student satisfaction with a higher education experience.

One research stream that is particularly relevant to our study is the literature relating to student satisfaction (Duarte et al., 2012; Voss, 2009). Student satisfaction can be defined as "an attitude resulting from an evaluation of students' educational experience, services and facilities" (Weerasinghe et al., 2017, p. 533). In services marketing, a service can hardly be separated from people. According to Zeithaml et al. (2017), there are several drivers of service satisfaction, which include the people participating in the service delivery. These include employees, customers, and other customers in the service environment. As previously discussed, students can be thought of as customers of a higher education service. Following Zeithaml et al. (2017), it is, therefore, arguable that students' encounters with other students are a part of a larger model of students' satisfaction with their classroom experience. By far, the most frequently studied aspects of student satisfaction are instructors' behaviors or attitudes (Davis \& Swanson, 2001; S. R. Swanson \& Davis, 2000), student-faculty interactions, and student perceptions of the quality of teaching (Vianden \& Yakaboski, 2017). There is a general dearth of research on student (dis)satisfaction with classroom-based, student-to-student interactions. Addressing this gap in the literature, our study uses the critical incident technique (CIT) to identify the types of student-to-student interactions that drive (dis)satisfaction with their educational experience.

Achieving a high satisfaction rate from students in HEIs is important for several reasons. First, satisfied students are more likely to succeed academically (Johnson, 2009). 
Students learn better when they perceive the classroom environment to be positive and supportive (Dorman et al., 2006). Second, there is a positive relationship between the level of student satisfaction and retention (i.e., intention to stay at the HEI; Suhre et al., 2007). A satisfied student population is highly sought after to engender loyalty, including positive word-of-mouth. This contributes to the enrollment of additional students, including high achievers who increase the reputation and standing of the university. Strategies aimed at improving student satisfaction have more positive effects on the brand equity of HEIs and on the success of student recruitment efforts than strategies that focus on building an institution's prestige (Dennis et al., 2016). Third, student satisfaction can also improve the institutions' performance and associated rankings (Douglas, McClelland, \& Davies, 2008). For example, student satisfaction (and dissatisfaction) is one of the many criteria that contributes to the university league table positions in the UK and that is reported annually in the National Student Satisfaction survey.

\section{Student-to-student interactions}

This study focuses on student-to-student interactions in the classroom setting. We posit that these interactions play a central role in marketing education experiences. We draw from wider research on customer-to-customer interactions (Grove \& Fisk, 1997; Huang, 2008; Nicholls, 2010; Söderlund, 2011), which are an important aspect of the overall service evaluation and are based on cues from explicit and implicit interactions with other customers (Lemke et al., 2011). While fellow customers can spoil a service experience through inappropriate behavior, they can also enhance it by providing informational and/or social support (Johnson \& Grier, 2013). Customer-to-customer interactions exert an important influence on the service experience and subsequent satisfaction with the service provider (Moore et al., 2005). Students are widely considered higher education customers (Bunce et al., 2017), and they increasingly demonstrate customer-like behavior (Nixon et al., 2018). 
Students spend several weeks or months together in one setting and develop relationships through interactions and common goals, which can either facilitate or impede learning (Swan, 2002). Interactions have an impact (Sidelinger \& Booth-Butterfield, 2010) on students' group collaboration (Colbeck et al., 2000), class involvement (Fassinger, 1997), communication with peers (Weaver \& Qi, 2005), the creation of cultural and social bonds (Kellogg \& Smith, 2009), and retention (Williams et al., 2006). Student-to-student interactions take place in marketing education in a variety of settings, including the classroom (e.g., lectures, seminars, tutorials), group assignments, coffee bars, dining rooms, libraries, social events, clubs, residence halls, workspaces, and university shops.

While the subject of student-to-student interactions has been addressed in the context of online courses (Kellogg \& Smith, 2009; Kurucay \& Inan, 2017; Swan, 2002), student-tostudent interactions in the classroom remain unexplored. To address this research gap, we investigate (dis)satisfactory student-to-student interactions in the classroom setting.

\section{Method}

\section{Study design}

We collected data using the CIT. Flanagan (1954) first described CIT as a method for collecting negative and positive incidents that contributed to the success or failure of a specific task. The CIT is a practical and efficient method that encourages participants to share their experiences with the researcher. It is a qualitative, systematic, and open-ended technique for gathering descriptive data from participants, which when correctly administered, produces content that is both qualitatively and quantitatively valuable (Grove \& Fisk, 1997). Moreover, CIT is an effective, naturalistic tool that focuses participants on a specific event (Sharoff, 2008) because it induces them to tell stories about the incidents or events that are the most critical, memorable, or important to them (Gremler, 2004; Vianden, 2012). Various studies in service marketing and management settings have employed CIT in an effort to better 
understand the types of encounters that can lead to customer (dis)satisfaction (Edvardsson, 1992; Gremler, 2004; Ramseook-Munhurrun, 2016). The CIT studies in educational settings have explored the perspectives of students (Davis \& Swanson, 2001; Douglas, McClelland, \& Davies, 2008; Swanson \& Davis, 2000; Voss, 2009; Voss et al., 2010), international students (Bianchi, 2013), English as a Second Language (ESL) students (Walker, 2015), and teachers (Harrison \& Lee, 2011; S. R. Swanson \& Frankel, 2002) to judge student satisfaction with elearning (Chen et al., 2008), the impact of cultural differences (Swanson et al., 2005), and services provided by university departments or administration (Chahal \& Devi, 2013). By giving participants the opportunity to freely describe their experiences, the CIT can provide useful insights into what drives satisfactory and dissatisfactory incidents. Therefore, it is an appropriate method for our study, which aims to identify the drivers of (dis)satisfactory classroom-based, student-to-student interactions in the context of marketing education.

We conducted the CIT-based study with marketing students at three HEIs to identify (dis)satisfying student-to-student interactions. We aimed to collect rich, qualitative, and critical incident-related data (Grove \& Fisk, 1997), as well as to identify events that were not always evident in other forms of the marketing students' experiences (Gremler, 2004). We presumed that all student-to-student interactions in the classroom were potential critical incidents (Angelides, 2001) that could suggest practical areas for improvement. Following established practice (e.g., Grove \& Fisk, 1997) and given that the questionnaire method is considered equivalent to interviews (Bott \& Tourish, 2016), our survey form included openended questions that allowed students to freely express themselves in their own words and in a detailed manner. We asked students enrolled in marketing courses to answer four questions (see Appendix). The questionnaire requested that students provide two critical incidents, one satisfactory and one dissatisfactory. Most respondents obligingly provided at least two incidents. 
We chose the respondents from three HEIs, two of which are located in Poland and one which is located in the UK. We maintained a diverse subject population profile by ensuring variations in age, gender, nationality, degree-level, and professional experience. The number of respondents was not predefined, and data collection stopped at the point where no new insights were generated through the collection of additional qualitative data. To maximize overall participation, we recruited students enrolled in marketing courses during their class time and developed a three-pronged communication strategy to increase student survey response rates. First, we explained the objectives of the study. Second, we shared a link to the online survey, and students decided voluntarily whether they wanted to participate. Third, after collecting data from students in each of the classes, we analyzed and interpreted the responses. By following this strategy, the new data eventually repeated what was expressed in previous data, and no new incidents were reported. Following the principle of saturation, we stopped collecting data at this point (Saunders et al., 2018).

The source questionnaire was in English. We translated the questionnaire into Polish, which is the first language of the majority of the respondents from Poland. Next, we translated each response back into English. We employed a forward and backward translation method to maintain equivalence in the test questionnaire of the target language. The research questions explored the qualitative nature of marketing students' perceptions of their remembered experiences, both positive and negative.

In total, we collected 844 incidents from 273 students of 27 nationalities during the spring and summer of 2017. The majority of respondents were Polish (75\%), followed by Ukrainian (4\%) and British (3\%). The age of the respondents ranged from 18 to 44 years, with 23 years as the average age. The sample contained $38 \%$ male and $62 \%$ female students, and $74 \%$ of respondents had at least one year of professional experience. Finally, $33 \%$ of 
respondents were enrolled in an undergraduate program, and $67 \%$ were enrolled in a postgraduate marketing program.

\section{Data analysis and reporting}

For the analysis, we used only critical incidents that contained a clear example of a satisfying or dissatisfying experience and that were described in enough detail to classify as incidents. We took five specific steps in the analysis of the CIT data. First, we determined our frame of reference, which included satisfactory or dissatisfactory student-to-student interactions in marketing education. Second, we compiled the data and categorized similar incidents into common categories using a deductive coding strategy (Miles \& Huberman, 1994). Third, we placed the categories into larger groups that served as the structure for reporting the results. For category development and data analysis, we used two coders (Coders A and B) and one

judge (Coder C) for verification. Coders A and B independently read all responses, sorted and re-read the critical incidents, and grouped similar factors into categories reflective of the major themes in the data. Fourth, we developed category names and comprehensive definitions. To establish the trustworthiness of the classifications that emerged, Coder C, who was not involved in the initial sorting effort, applied the classification system to the complete set of incidents (Grove \& Fisk, 1997). Intercoder reliability is a critical component in the content analysis of open-ended survey responses, without which the interpretation of the content would not be considered objective and valid (Lavrakas, 2019). Coder C re-examined the data to gauge the validity of categories and definitions, resulting in a $97 \%$ intercoder reliability rate. Finally, disagreements over categories were discussed between the coders to reach a final agreement on the coding.

\section{Findings}

\section{Incident classification system}


The primary benefit of using the CIT is the resulting groups and categories that emerge through the classification procedure (Grove \& Fisk, 1997). In this section, we describe the groups and categories, depicted in Figure 1, that emerged in our study.

Insert Figure 1 about here.

The CIT classification system consists of three major groups that account for satisfactory and dissatisfactory incidents: (a) group assignments, (b) peer relations, and (c) outcomes. We classified all 844 incidents into one of these three groups and their eleven categories to provide a clearer picture of the factors leading to satisfaction and dissatisfaction in classroom-based, student-to-student interactions. Table 1 lists these groups and categories with the corresponding percentages.

Insert Table 1 about here.

\section{Group 1. Group assignments}

All Group 1 incidents $(n=250)$ are directly related to group assignments. Incidents in this group reflect the rules that specify how a group assignment should be organized and what constitutes satisfactory and dissatisfactory participation. Four categories emerged in the group assignments group: group composition, group size, division of labor, and group processes. Table 2 provides examples of incidents from these four categories.

Insert Table 2 about here.

\section{A. Group composition.}

This category deals with incidents that refer to the attributes of students that comprise the group. According to our results, students appreciate working with peers who they believe are similar to them. More specifically, students relate to similar personalities in other group 
members, particularly in regard to their trustworthiness and reliability. Another set of attributes relate to similar dedication to work. Attributes such as the willingness to commit to the group assignment and eagerness to work are important sources of student satisfaction. Conversely, working with peers with dissimilar personalities and dedication to work can cause dissatisfaction.

\section{B. Group size.}

This category includes incidents that reflect perceptions of group size. According to our results, in large groups there are more individual schedules to accommodate and opinions to consider. Larger groups also present a greater threat of "free-riding." Therefore, groups that are perceived as being too large cause dissatisfaction among the affiliated members.

\section{C. Division of labor.}

This category includes incidents related to the division of labor, which is defined as the assignment of different tasks to different people (Strauss, 1985). As such, this category deals with three distinct types of incidents regarding the division of labor: participation in the labor division, understanding of roles and responsibilities, and equity of labor division. The results show that students regard the division of labor as satisfactory if they can participate in the decision-making. The second type of incident within this category refers to a group member's understanding of each member's role and responsibility (i.e., the labor to be provided), including their own. For a satisfactory experience, students must be sufficiently clear about the task expectations for themselves and others regarding the group work assignment. A lack of clarity regarding group members' roles and responsibilities can lead to feelings of confusion, creating dissatisfaction among group members. The third type of incidents in this category concerns group members' perceptions of equity regarding the division of labor. These perceptions included factors such as the quantity of individual work and the associated amount of time required for the group work assignment. One of the greatest causes of 
frustration among students was that labor had not been equitably divided, leaving some group members to do more work than others.

\section{D. Group processes.}

This category reflects incidents that refer to group processes, which is defined as the actions of members of small working groups as they engage in task performance (Stangor, 2017). Positive incidents in this category include providing mutual support, showing a willingness to compromise to resolve conflicts, and solving problems as a group. The dissatisfying incidents include insufficient support for group members in need, unwillingness to compromise, and coercion as a means of resolving problems.

\section{Group 2. Peer relations}

When students have to share space and time with each other in the classroom, their experiences are affected by their peers. The second group of critical incidents $(n=334)$ emerge from student-to-student interactions, which are a vital part of any course experience. In a classroom setting, these interactions happen naturally, as students build rapport through frequent and regular contact. The respondents mentioned several dimensions of peer relations under the scope of this broad category of responses. Incidents in this group were categorized into three categories: social-servicescape, behavior, and cultural aspects. The first refers to attributes of the classroom's social-servicescape. The second references individual student behaviors, and the third category addresses aspects of cultural diversity in the classroom. Table 3 provides examples of critical incidents from all three categories.

Insert Table 3 about here.

\section{A. Social-servicescape.}


This category reflects incidents associated with the social-servicescape concept. The socialservicescape refers to the way in which a socially-oriented service environment influences customer emotions, highlighting the significance of customer-to-customer emotional contagion within a service environment (Line \& Hanks, 2018; Tombs \& McColl-Kennedy, 2003). We view the classroom as a socially-oriented service environment in which studentto-student interactions take place, and this category describes incidents influenced by attributes of the classroom's social-servicescape.

This category deals with three distinct types of incidents related to different attributes of a classroom's social-servicescape, describing the extent to which it is inclusive, unified, and relaxed. The first set of incidents refers to classroom inclusiveness. According to our results, students appreciate an open and tolerant classroom environment in which they can freely discuss problems and others understand their ideas. In such an environment, students feel that they are accepted and respected by peers and belong to the community. Conversely, students' classroom experiences may be dissatisfactory when they feel excluded from freely expressing their views, misunderstood, or ignored. Moreover, when some students divide themselves into separate, exclusive groups, it may cause their peers to feel isolated, overlooked, and unappreciated.

The second set of incidents in this category reflects the sense of unity and cohesion of a classroom. Students are satisfied when they cooperate to achieve a unifying common goal. Contrarily, situations where students are not unified can cause dissatisfaction.

The third set of incidents in this category refers to the relaxed atmosphere in a classroom. When peers are easy-going, studying is easier and more fun. Stress is alleviated in the class, especially in cases like speaking in front of an audience. Students also appreciate other students who wish them well, such as during exams. We also discovered dissatisfying 
incidents that arose from tense classroom atmospheres. Students do not like to feel pressure from their peers. The pressure may result from competition associated with a "rat-race" atmosphere and a "fight" for grades.

\section{B. Behavior.}

A significant number of incidents focused on student behavior, which we define as the way individual students act in the classroom. This category deals with five distinct types of incidents related to individual student behavior: helpfulness, disruptive behavior, academic dishonesty, rudeness, and arrogance. The first set of incidents in this category refers to the helpfulness of other students. If other students provide support and help with solving problems, preparing for exams, sharing notes, or passing on exam questions or other learning materials from previous years, it can affect peer interactions in a positive way. In contrast, unhelpful behavior can cause dissatisfaction. Specific examples include cases when students are selfish, do not want to help, do not want to share notes or knowledge about exam materials, or refuse to reveal relevant information.

The second set of incidents refers to the disruptive behavior of other students, which can cause dissatisfaction. We identified several unacceptable student behaviors from other students' perspectives. Some students identified disruptive behavior as talking loudly, eating, texting, playing on the Internet, or instant messaging in class. When a student arrives late, the classroom is disrupted. Furthermore, there were examples of verbal disturbance. While questions and classroom participation are often encouraged, some students can become disruptive by talking out of turn, monopolizing the teacher's time by asking irrelevant questions, or by dominating classroom discussions. Students are also annoyed when individuals speak "on behalf" of the group when their opinions are not universal. 
The third set of incidents refers to academic dishonesty. This subcategory includes incidents such as cheating, signing in absentia, copying parts of another group's project, and intentionally missing exams (e.g., to get questions ahead of time). Other examples of negative behavior include duplicity, disinformation, and uploading intentionally false notes so that other students will obtain poor results.

The fourth set of incidents refers to student rudeness. Dissatisfactory incidents include individuals making rude comments to other students, harshly rejecting comments outrightly, impolitely pointing out other's mistakes, and impertinently talking back to others, including the teachers.

The last set of incidents refers to the arrogant behavior of other individuals in the classroom. Dissatisfactory incidents included situations in which individual students not only think that they are better than others or feel smarter than others but also show it to their peers. Other dissatisfactory incidents in this category included a sense of "showing off" among peers.

\section{C. Cultural aspects.}

Students who learn in a diverse classroom environment are exposed to a variety of cultures and ethnic backgrounds (Hofstede, 1986). This creates potential challenges for students (Apfelthaler et al., 2007). We discovered positive and negative aspects of cultural diversity in the classroom. The satisfactory incidents relate to the fact that interacting with students from different cultures can be a learning experience in itself, providing insights that textbooks alone cannot offer. Students become more aware of these cultures and learn interesting and new facts about them (e.g., punctuality, diligence). Awareness also helps students show respect and sensitivity to other cultures and correct stereotypes. In addition, some students reported that they appreciated the opportunity to interact with people from other cultures, 
which stimulated communication and curiosity. As such, diverse group projects are broader and more interesting.

In contrast, we also identified examples of dissatisfactory intercultural relations. Spreading stereotypes and having different perceptions of time, noise, or physical comfort can result in dissatisfactory incidents related to cultural differences. Cultural differences can also cause communication problems. Incoming students may feel isolated from other students because of a language barrier (e.g., Ukrainian students in Poland), or international students may form groups that use a different language (e.g., a British student in Newcastle did not understand Korean peers speaking Korean). There are also cultural differences in learning styles and levels of knowledge between students that also make the communication process difficult. Foreign students may also use translators during exams, which some domestic students deem unfair.

Insert Table 4 about here.

\section{Group 3. Outcomes}

Group 3 includes incidents $(\mathrm{n}=260)$ related to the impact of classroom peers on individual student achievement. Other students can have either a positive or negative effect on learning outcomes in the classroom. Incidents in this category of response reflect how peers affect the acquisition of skills or knowledge, student success, and the studying experience. Four categories emerged in the outcomes group: peer learning, performance, personal growth, and experiences. Table 4 provides samples of critical incidents from the four categories.

\section{A. Peer learning.}


We follow Bacon (2016) in defining learning as the acquisition of knowledge and skills. Peer learning is a reciprocal learning activity that involves the sharing of knowledge, ideas, and experience among students (Boud et al., 1999).

Students listed several positive outcomes of peer learning in this category. As a result of preparing for exams together or having difficult learning material explained by peers, students gained content knowledge which they would have not otherwise acquired. Moreover, peer learning fosters the development of skills, such as self-directed learning, critical thinking, problem solving, and presentation skills. Peer learning also stimulates creativity and allows for different perspectives and novel ways of thinking. Contrarily, students are dissatisfied when they did not believe they had learned anything new from their peers and when they felt that they gave other students more than they received.

\section{B. Performance.}

Other students can have either a positive or negative effect on performance in the classroom. This category deals with two distinct types of incidents: those related to the quality of work and the associated grades and those related to common aspirations for the final grade.

The first set of incidents refers to the quality of work and the associated grades. Satisfactory incidents include situations in which students obtained better grades resulting from an interaction with peers. For example, working with peers may help students improve the quality of their work and enhance presentations. Another potentially satisfying factor is the possibility of presenting the results of the work together, as skilled presenters can impress both teachers and other groups. At the same time, we observed factors that contributed to bad grades and led to dissatisfaction. The most common examples include providing lower standards of work or not delivering the assigned work on time or at all by some group members, which in turn affected the grades of the more diligent peers. Another set of 
dissatisfactory incidents in this subcategory refers to unfairness in grading. Students feel particularly dissatisfied when other students who do not contribute equally to the group project still receive the same grades as the other hardworking members. Cheating to obtain better grades also contributed to a sense of unfairness.

The second set of incidents refers to shared grade aspirations. Students are satisfied when other students exhibit common aspirations for the final grade. Contrarily, if other students have different perceptions of what constitutes a good grade, it may cause dissatisfaction.

\section{C. Personal growth.}

This category includes incidents related to personal development and professional advancement. It contains two distinct types of incidents: gaining confidence and building professional networks. The first set of incidents refers to gaining confidence. Students can gain self-confidence through interactions with their peers. They feel a greater sense of competency in their abilities, and this feeling enhances their sense of personal worth. However, peer interaction can also lead to negative outcomes in the case of self-confidence. Dissatisfactory student interactions mainly refer to a lack of confidence and low self-esteem resulting from classroom interactions with better performing students who created a challenging reference point.

The second set of incidents refers to building professional networks and contacts for the future. Students are satisfied when building professional networks may increase their chances of finding new jobs or business opportunities.

\section{D. Experiences.}

This category reflects incidents related to individual experiences of fun, enjoyment, and wellbeing as an outcome of student-to-student interactions in the classroom. Students are satisfied 
when they feel emotionally connected with the their peers and can spend time and have fun together. In general, they like to meet new, interesting, and funny people with similar interests and want to feel that what they do has value. Students enjoy participating in classroom activities, especially conducting marketing experiments. Positive friendship experiences, such as meeting a best friend or even finding love, are associated with individual happiness. Other students can also create positive social experiences beyond the classroom by recommending fascinating books, movies, or websites and sharing information about price discounts or interesting services or products.

However, student-to-student interactions in the classroom can also lead to negative experiences for individuals. Students are dissatisfied when some peers do not want to integrate with or belong to a group and do not participate appropriately in classroom social activities. Sometimes, students' experiences are also spoiled by the number of other students present (e.g., crowded lecture theatres).

\section{Discussion}

\section{Implications for research}

Student experience has emerged as an important competitive factor for HEIs (Bunce et al., 2017; Tan et al., 2016; Temple et al., 2014). The study’s findings advance the understanding of interactions among marketing students and their consequences on student satisfaction. We empirically derived a classification (three groups and eleven categories) of student-to-student interactions, which are characterized by specific satisfiers and dissatisfiers. The 844 incidents reported by the marketing students provide novel insights into the classroom experience, as well as the nature and relative importance of the factors leading to satisfaction and dissatisfaction in the context of marketing education experiences. 
While our percentage of satisfactory incidents in the group assignment category is supportive of Gregory and Thorley's (2013) observation that group work is considered to be an attractive method for teaching and learning in HE, the relatively high percentage of dissatisfactory incidents connected with this category point to a potential "dark side" of group assignments. This is consistent with Soetanto and MacDonald (2017), who also identify that negativity stems from issues with managing labor division, the equitable assignment of roles and responsibilities, and failure to ensure positive intra-group collaboration. Similarly, Pfaff and Huddleston's (2003) research reports that unequal workload is the most common dissatisfier in student group work. Furthermore, research by Aggarwal and O’Brien (2008) also documents that "social loafing" is an important problem in student groups. While Neu (2012) previously identified several of these factors as relevant to group assignments, our study is able to provide further insights regarding their relative importance in driving student (dis)satisfaction concerning classroom-based, student-to-student interactions.

The peer relations group of incidents were relatively balanced in terms of their positivity and negativity, with a slight skew towards the number of negative events reported. Therefore, our research confirms that student behavior has the potential to create, reduce, or destroy classroom satisfaction for other students. According to our findings, the behavior of other students is the major driver of students' overall satisfaction with peer interactions. The behavior category comprises over one fifth of total satisfactory incidents reported. This paper also contributes to a broadening of the application of the social-servicescape model, as well as to a greater understanding of what factors constitute the classroom social environment and what makes this environment appealing to prospective students. In agreement with Fredricks et al. (2011), we found that peers with a positive academic orientation share information, work cooperatively, and show behavioral, cognitive, and emotional engagement. Our study 
also further confirms that interactions with peers have an impact on the student experience in multicultural classrooms (Lee et al., 2014).

The outcomes group incidents are related to the impact of classroom peers on individual student achievement. Our findings suggest that in this group, students are more likely to recall positive rather than negative incidents in the context of classroom-based peer interactions. This is particularly important because, according to Bacon et al. (1999), students learn more from a "good" classroom experience than they learn from a "bad" classroom experience. Students who have a "good" classroom experience not only enjoy working with other students, but their groups generally perform well academically, leading to satisfaction with the course (Bacon et al., 1999). Therefore, the results of our study confirm that peer learning style is a key factor in achieving student satisfaction, which leads to better learning performance.

Other students (i.e., customers) are one of key groups of people participating in the HEI's service delivery that influences student perceptions (Zeithaml et al., 2017). Therefore, we contribute to better understanding of the people element of services marketing mix by examining the existence, nature, variety, and impact of student-to-student interactions in a classroom setting and their potential for creating student (dis)satisfaction. By explaining this phenomenon, we also contribute to the general discussion on drivers of students' satisfaction with the classroom experience (Gibson, 2010; Mark, 2013).

This study also makes contributions to the existing literature on customer-to-customer interactions by answering Lee et al.'s (2019) call for more research on interactions with other customers in different service settings. More specifically, our study focuses on higher education services and on understanding the drivers of students' (dis)satisfaction regarding classroom-based, student-to-student interactions in marketing education. 


\section{Implications for practice}

This study's findings also have implications for marketing education. It is essential for both HEI managers and marketing instructors to understand student-to-student interactions and identify drivers of student (dis)satisfaction. In doing so, business schools will be able to better manage marketing students' experiences to the benefit of the institution. In particular, business schools should not only attempt to strengthen the drivers of student satisfaction, but they should also identify, minimize, and eliminate the causes of dissatisfaction (Bianchi, 2013). Faculty members primarily manage interactions between marketing students and often recognize unsatisfactory encounters (Swanson \& Frankel, 2002). Not only should faculty members work to prevent negative incidents from occurring, but they should also promote activities in which students can interact in nonthreatening ways (Hagedorn et al., 2000). As such, we first discuss what our findings mean for marketing instructors and formulate specific (i.e., tactical) recommendations based on the three overarching incident groups identified in our study: group assignments, peer relations, and outcomes.

For the group assignments category, our findings primarily draw attention to the group formation stage. Based on our findings, we recommend instructors avoid creating larger groups due to the risk of "free-riding." Once the groups have been formed, marketing educators should manage group assignments by providing an overview of the expected division of labor and group processes. Based on pedagogy literature (Ko, 2014), we recommend that instructors provide clear guidance (e.g., in the form of a relevant section in the course handout/book) regarding the process of labor division, including the equitable assignment of roles and responsibilities among group members. Instructors should also follow up by checking that the roles and responsibilities are clearly understood and that the workload within each group is equitably distributed. To prevent any potential problems regarding group processes, students should be informed that group grades will be adjusted 
based on their peers' assessments of their contribution (Brutus \& Donia, 2010). Such grade adjustments could complement conventional methods of assessment and could serve as an incentive for greater student contribution to the group.

Based on our findings for the peer relations group, we propose that marketing instructors should create an environment that is conducive to in-class, student-to-student interactions. Drawing on services marketing literature on designing physical environments (Zeithaml et al., 2017), we recommend that in cases where instructors can control room requirements, classes should take place in a non-tiered classroom with tables and chairs set up for group work. Regarding the social environment, we recommend that students be given the opportunity to get to know one another at the start of a course to feel comfortable with the group setting from the beginning. To achieve this, instructors could use icebreakers or teambuilding exercises. Instructors should also swiftly challenge any problematic classroom attitudes and behaviors, such as microaggressions, or offensive and alienating comments.

For the outcomes group, our findings show that students usually want to be surrounded by peers with similar personalities. However, this finding is not meant to imply that groups should only be composed of similar students. On the contrary, we argue that it is neither possible to create groups of students with similar personalities, nor it is desirable to create such groups. On the one hand, instructors cannot realistically assess students' personalities. On the other hand, dissimilarity in groups is important for learning about working with different types of people (Hobman et al., 2003). Therefore, it is important for instructors to help students develop a meaningful appreciation for differences. This could be achieved by assigning roles with specific privileges, obligations, responsibilities and powers to students. All group members should rotate through these roles so that students gain experience in all roles and leadership positions (Orlich et al., 2013). In this way, students can share their strengths and learn new skills from their peers, developing meaningful 
appreciation of other students in the process. We also suggest that instructors encourage students in their personal growth beyond the acquisition of subject-specific knowledge and skills. Student should develop effective communication and listening skills. The ability to resolve intra-group conflicts can be considered an important aspect of personal growth and an enabler of enriching experiences. For example, instructors should encourage students to practice emotional distancing techniques to avoid emotional outbursts during conflicts.

Our findings also allow us to provide strategic recommendations for HEI managers, which may be helpful in setting appropriate goals and prioritizing initiatives that decrease dissatisfactory student experiences to improve student recruitment, retention, and financial stability. In reference to the customer-to-customer interactions literature, we recommend creating a supportive environment for educators who deal with student-to-student interactions. This includes providing effective human resource management, such as employee selection, development and training opportunities, as well as rewards and incentives (Nicholls, 2005). Support and training in these issues are particularly important because educators often feel insecure about managing student interactions. Implementing policies that aim to diminish or eliminate dissatisfying interactions between students, such as identifying and analyzing students' complaints or course evaluation comments, could also support educators in the classroom. HEI managers could also actively investigate the extent to which instructors observe negative interactions in the classroom and the response to these incidents. To provide a full picture, HEI managers should also consider the students' assessments of instructors' reactions to reported negative situations.

\section{Limitations and future research directions}

Although this study is one of the few to advance new knowledge on student-to-student interactions in the context of marketing education, it has several limitations. First, the study's 
chosen method is inherently limited. Although use of the CIT was appropriate, this method relies on the respondents' recall of previous classroom experiences. Therefore, there may be a possible bias toward recent incidents, as these are easier to recall. In addition, the written student narratives were not always detailed enough to permit an accurate analysis and categorization. Finally, we only analyzed the critical incidents that directly concerned our focus on satisfactory and dissatisfactory incidents. There were many more neutral responses from the cohorts. Hence, we have removed a subset of student experiences that were not appropriate for the analysis. As a result, it is not possible to make any general assumptions beyond the investigated context.

Second, the study is limited by its relatively small sample size and its specific context (i.e., marketing students within the field of business and management in the UK and Poland). We conducted our research in a specific regional context, which may affect the specificity of the student-to-student interactions. We encourage further investigation of this phenomenon across marketing HEIs in other countries and with students representing culturally diverse populations. Future studies could also replicate our study in a virtual classroom context or investigate different cultural contexts to support any generalization of the findings. The results regarding the most significant dissatisfying factors of group assignments (i.e., coercive, uncompromising behavior and prioritization of self-interest) suggest potential cultural moderation along the individualism/collectivism dimensions.

Third, our sample included both undergraduate and postgraduate students. We understand that these are different types of students, and the results of the study may be variable across the two populations. We have used the chi-squared test to determine whether there is a statistically significant difference between undergraduate and postgraduate students, but the test did not show any statistical differences. We encourage future researchers to consider this issue in greater detail. 
Fourth, the theoretical framework in this paper is based on the concept of student experience. However, there are several interesting theoretical approaches that could be applied in the context of classroom-based, student-to-student interactions in future research. Students play an active role in creating the value of the university service (Díaz-Méndez \& Gummesson, 2012). Increasingly prominent research on value co-creation in HE, which focuses on the high levels of collaboration between students (Bovill, 2020; Smørvik \& Vespestad, 2020), could be applied to explore how value is co-created in student-to-student interactions. In addition, customer journey mapping approaches may have some applicability to this topic (Hamilton \& Price, 2019).

Fifth, higher education is somewhat unique in that the quality of customers for any given program may differ based on admission standards. Depending on the institution, different levels of student qualifications are required for enrollment. HEIs may enroll students via open admissions, selective admissions, or elite admissions processes. Therefore, it is likely that certain programs and business schools may host classes of students that are more serious about doing well on assignments and who have a greater sense of shared purpose than in other programs. As such, these programs may achieve higher quality studentto-student interactions and produce higher quality group assignments. The effect of HEIs' selection process on student-to-student interactions in the classroom could be a potential avenue for future research.

Finally, students' encounters with other students, while important, are just one antecedent in a much larger model of student satisfaction with the classroom experience. Hence, there is a need for further research to investigate the impact of student-to-student interactions in relation to other factors like teaching quality and course organization on students' overall HE experience. 


\section{References}

Aggarwal, P., \& O’Brien, C. L. (2008). Social Loafing on Group Projects: Structural Antecedents and Effect on Student Satisfaction. Journal of Marketing Education, 30(3), 255-264. https://doi.org/10.1177/0273475308322283

Angelides, P. (2001). The development of an efficient technique for collecting and analyzing qualitative data: The analysis of critical incidents. International Journal of Qualitative Studies in Education, 14(3), 429-442. https://doi.org/10.1080/09518390110029058

Apfelthaler, G., Hansen, K., Keuchel, S., Mueller, C., Neubauer, M., Ong, S. H., \& Tapachai, N. (2007). Cross-cultural Differences in Learning and Education: Stereotypes, Myths and Realities. In D. Palfreyman \& D. L. McBride (Eds.), Learning and Teaching Across Cultures in Higher Education (pp. 15-35). Palgrave Macmillan UK. https://doi.org/10.1057/9780230590427_2

Arambewela, R., Hall, J., \& Zuhair, S. (2006). Postgraduate International Students from Asia: Factors Influencing Satisfaction. Journal of Marketing for Higher Education, 15(2), 105-127. https://doi.org/10.1300/J050v15n02_05

Bacon, D. R. (2016). Reporting Actual and Perceived Student Learning in Education Research. Journal of Marketing Education, 38(1), 3-6. https://doi.org/10.1177/0273475316636732

Bacon, D. R., Stewart, K. A., \& Silver, W. S. (1999). Lessons from the Best and Worst Student Team Experiences: How a Teacher can make the Difference. Journal of Management Education, 23(5), 467-488. https://doi.org/10.1177/105256299902300503 
Baranova, P., Morrison, S., \& Mutton, J. (2011). Enhancing the student experience through service design. Perspectives: Policy and Practice in Higher Education, 15(4), 122128. https://doi.org/10.1080/13603108.2011.599883

Bateson, R., \& Taylor, J. (2004). Student Involvement in University Life-Beyond Political Activism and University Governance: A view from Central and Eastern Europe. European Journal of Education, 39(4), 471-483. https://doi.org/10.1111/j.14653435.2004.00198.x

Benckendorff, P., Ruhanen, L., \& Scott, N. (2009). Deconstructing the Student Experience: A Conceptual Framework. Journal of Hospitality and Tourism Management, 16(1), 8493. https://doi.org/10.1375/jhtm.16.1.84

Bianchi, C. (2013). Satisfiers and dissatisfiers for international students of higher education: An exploratory study in Australia. Journal of Higher Education Policy and Management, 35(4), 396-409. https://doi.org/10.1080/1360080X.2013.812057

Bolton, R., McColl-Kennedy, J., Sirianni, N., Gustafsson, A., \& Tse, D. (2014). Small details that make big differences: A radical approach to consumption experience as a firm's differentiating strategy. Journal of Service Management, 25(2), 253-274. https://doi.org/10.1108/JOSM-01-2014-0034

Bott, G., \& Tourish, D. (2016). The critical incident technique reappraised: Using critical incidents to illuminate organizational practices and build theory. Qualitative Research in Organizations and Management: An International Journal, 11(4), 276-300. https://doi.org/10.1108/QROM-01-2016-1351

Boud, D., Cohen, R., \& Sampson, J. (1999). Peer Learning and Assessment. Assessment \& Evaluation in Higher Education, 24(4), 413-426. https://doi.org/10.1080/0260293990240405 
Bovill, C. (2020). Co-creation in learning and teaching: The case for a whole-class approach in higher education. Higher Education, 79(6), 1023-1037. https://doi.org/10.1007/s10734-019-00453-w

Brutus, S., \& Donia, M. B. L. (2010). Improving the Effectiveness of Students in Groups With a Centralized Peer Evaluation System. Academy of Management Learning \& Education, 9(4), 652-662. https://doi.org/10.5465/amle.9.4.zqr652

Bunce, L., Baird, A., \& Jones, S. E. (2017). The student-as-consumer approach in higher education and its effects on academic performance. Studies in Higher Education, 42(11), 1958-1978. https://doi.org/10.1080/03075079.2015.1127908

Canning, J. (2017). Conceptualising student voice in UK higher education: Four theoretical lenses. Teaching in Higher Education, 22(5), 519-531. https://doi.org/10.1080/13562517.2016.1273207

Chahal, H., \& Devi, P. (2013). Identifying satisfied/dissatisfied service encounters in higher education. Quality Assurance in Education, 21(2), 211-222. https://doi.org/10.1108/09684881311310728

Chen, N.-S., Lin, K.-M., \& Kinshuk. (2008). Analysing Users' Satisfaction with E-Learning Using a Negative Critical Incidents Approach. Innovations in Education and Teaching International, 45(2), 115-126.

Colbeck, C. L., Cabrera, A. F., \& Terenzini, P. T. (2000). Learning professional and confidence: Linking teaching practices, students' self perceptions, and gender. Review of Higher Education, 24, 173-191.

Conaway, R. N., Easton, S. S., \& Schmidt, W. V. (2005). Strategies for Enhancing Student Interaction and Immediacy in Online Courses. Business Communication Quarterly, $68(1), 23-35$. 
Davis, J. C., \& Swanson, S. T. (2001). Navigating Satisfactory and Dissatisfactory Classroom Incidents. Journal of Education for Business, 76(5), 245-250. https://doi.org/10.1080/08832320109599643

Dennis, C., Papagiannidis, S., Alamanos, E., \& Bourlakis, M. (2016). The role of brand attachment strength in higher education. Journal of Business Research, 69(8), 30493057. https://doi.org/10.1016/j.jbusres.2016.01.020

DeShields, O. W., Kara, A., \& Kaynak, E. (2005). Determinants of business student satisfaction and retention in higher education: Applying Herzberg's two-factor theory. International Journal of Educational Management, 19(2), 128-139. https://doi.org/10.1108/09513540510582426

Díaz-Méndez, M., \& Gummesson, E. (2012). Value co-creation and university teaching quality: Consequences for the European Higher Education Area (EHEA). Journal of Service Management, 23(4), 571-592. https://doi.org/10.1108/09564231211260422

Dorman, J. P., Aldridge, J. M., \& Fraser, B. J. (2006). Using Students’ Assessment of Classroom Environment to Develop a Typology of Secondary School Classrooms. International Education Journal, 7(7), 906-915.

Douglas, A., Douglas, J., \& Barnes, B. (2006). Measuring student satisfaction at a UK university. Quality Assurance in Education, 14(3), 251-267. https://doi.org/10.1108/09684880610678568

Douglas, J., McClelland, R., \& Davies, J. (2008a). The development of a conceptual model of student satisfaction with their experience in higher education. Quality Assurance in Education, 16(1), 19-35. https://doi.org/10.1108/09684880810848396

Douglas, J., McClelland, R., \& Davies, J. (2008b). The development of a conceptual model of student satisfaction with their experience in higher education. Quality Assurance in Education, 16(1), 19-35. https://doi.org/10.1108/09684880810848396 
Duarte, P. O., Raposo, M. B., \& Alves, H. B. (2012). Using a Satisfaction Index to Compare Students' Satisfaction During and After Higher Education Service Consumption. Tertiary Education and Management, 18(1), 17-40. https://doi.org/10.1080/13583883.2011.609564

Edvardsson, B. (1992). Service Breakdowns: A Study of Critical Incidents in an Airline. International Journal of Service Industry Management, 3(4), 17-29. https://doi.org/10.1108/09564239210019450

Fassinger, P. A. (1997). Classes Are Groups: Thinking Sociologically about Teaching. College Teaching, 45(1), 22-25. https://doi.org/10.1080/87567559709596184

Fredricks, J. A. (2011). Engagement in School and Out-of-School Contexts: A Multidimensional View of Engagement. Theory Into Practice, 50(4), 327-335. https://doi.org/10.1080/00405841.2011.607401

Friman, M., Gustafsson, A., Perks, H., Jaakkola, E., Radnor, Z. J., Klaus, P., \& McCollKennedy, J. R. (2015). Fresh perspectives on customer experience. Journal of Services Marketing, 29(6/7), 430-435. https://doi.org/10.1108/JSM-01-2015-0054

Ghosh, A. K., Javalgi, R., \& Whipple, T. W. (2008). Service Strategies for Higher Educational Institutions Based on Student Segmentation. Journal of Marketing for Higher Education, 17(2), 238-255. https://doi.org/10.1080/08841240801912641

Gibson, A. (2010). Measuring business student satisfaction: A review and summary of the major predictors. Journal of Higher Education Policy and Management, 32(3), 251259. https://doi.org/10.1080/13600801003743349

Grace, D., Weaven, S., Bodey, K., Ross, M., \& Weaven, K. (2012). Putting student evaluations into perspective: The Course Experience Quality and Satisfaction Model (CEQS). Studies in Educational Evaluation, 38(2), 35-43. https://doi.org/10.1016/j.stueduc.2012.05.001 
Gray, D. M., Peltier, J. W., \& Schibrowsky, J. A. (2012). The Journal of Marketing Education: Past, Present, and Future. Journal of Marketing Education, 34(3), 217237. https://doi.org/10.1177/0273475312458676

Gregory, R., \& Thorley, L. (2013). Using Group-based Learning in Higher Education. Routledge. https://doi.org/10.4324/9781315041506

Gremler, D. D. (2004). The Critical Incident Technique in Service Research. Journal of Service Research, 7(1), 65-89. https://doi.org/10.1177/1094670504266138

Grove, S. J., \& Fisk, R. P. (1997). The impact of other customers on service experiences: A critical incident examination of "getting along.” Journal of Retailing, 73(1), 63-85. https://doi.org/10.1016/S0022-4359(97)90015-4

Gruber, T., Lowrie, A., Brodowsky, G. H., Reppel, A. E., Voss, R., \& Chowdhury, I. N. (2012). Investigating the Influence of Professor Characteristics on Student Satisfaction and Dissatisfaction: A Comparative Study. Journal of Marketing Education, 34(2), 165-178. https://doi.org/10.1177/0273475312450385

Guilbault, M. (2016). Students as customers in higher education: Reframing the debate. Journal of Marketing for Higher Education, 26(2), 132-142. https://doi.org/10.1080/08841241.2016.1245234

Hagedorn, L., \& Maxwell, W. (2000). Peer and Student-Faculty Relations In Community Colleges. Community College Journal of Research and Practice, 24(7), 587-598. https://doi.org/10.1080/10668920050139730

Hamilton, R., \& Price, L. L. (2019). Consumer journeys: Developing consumer-based strategy. Journal of the Academy of Marketing Science, 47(2), 187-191. https://doi.org/10.1007/s11747-019-00636-y 
Harris, K., Baron, S., \& Parker, C. (2000). Understanding the Consumer Experience: It's “Good To Talk.” Journal of Marketing Management, 16(1-3), 111-127. https://doi.org/10.1362/026725700785100505

Harrison, J. K., \& Lee, R. (2011). Exploring the use of critical incident analysis and the professional learning conversation in an initial teacher education programme. Journal of Education for Teaching, 37(2), 199-217. https://doi.org/10.1080/02607476.2011.558285

Herdlein, R., \& Zurner, E. (2015). Student Satisfaction, Needs, and Learning Outcomes: A Case Study Approach at a European University. SAGE Open, 5(2), 2158244015580373. https://doi.org/10.1177/2158244015580373

Hobman, E. V., Bordia, P., \& Gallois, C. (2003). Consequences of Feeling Dissimilar from Others in a Work Team. Journal of Business and Psychology, 17(3), 301-325. https://doi.org/10.1023/A:1022837207241

Hofstede, G. (1986). Cultural differences in teaching and learning. International Journal of Intercultural Relations, 10(3), 301-320. https://doi.org/10.1016/0147-1767(86)900155

Huang, W. (2008). The impact of other-customer failure on service satisfaction. International Journal of Service Industry Management, 19(4), 521-536. https://doi.org/10.1108/09564230810891941

Jabbar, A., Analoui, B., Kong, K., \& Mirza, M. (2018). Consumerisation in UK higher education business schools: Higher fees, greater stress and debatable outcomes. Higher Education, 76(1), 85-100. https://doi.org/10.1007/s10734-017-0196-Z

John, P., \& Fanghanel, J. (Eds.). (2016). Dimensions of marketisation in higher education. Routledge, Taylor \& Francis Group. 
Johnson, D. I. (2009). Connected Classroom Climate: A Validity Study. Communication Research Reports, 26(2), 146-157. https://doi.org/10.1080/08824090902861622

Johnson, G. D., \& Grier, S. A. (2013). Understanding the influence of cross-cultural Consumer-to-Consumer Interaction on consumer service satisfaction. (1)Reconceptualizing Cross-Cultural Research in the Digital Age (2)Advances in Business Research in Latin America Studies, 66(3), 306-313. https://doi.org/10.1016/j.jbusres.2011.08.010

Jones, R. (2018). The student experience of undergraduate students: Towards a conceptual framework. Journal of Further and Higher Education, 42(8), 1040-1054. https://doi.org/10.1080/0309877X.2017.1349882

Kellogg, D. L., \& Smith, M. A. (2009). Student-to-Student Interaction Revisited: A Case Study of Working Adult Business Students in Online Courses. Decision Sciences Journal of Innovative Education, 7(2), 433-456. https://doi.org/10.1111/j.15404609.2009.00224.x

Ko, J., Sammons, P., \& Bakkum, L. (2013). Effective teaching: A review of research and evidence. Hong Kong: Hong Kong Institute of Education; Berkshire: CfBT Education Trust.

Kurucay, M., \& Inan, F. A. (2017). Examining the effects of learner-learner interactions on satisfaction and learning in an online undergraduate course. Computers \& Education, 115, 20-37. https://doi.org/10.1016/j.compedu.2017.06.010

Lavrakas, P. (2019). Encyclopedia of Survey Research Methods. https://doi.org/10.4135/9781412963947

Lee, A., Williams, R. D., Shaw, M. A., \& Jie, Y. (2014). First-year students' perspectives on intercultural learning. Teaching in Higher Education, 19(5), 543-554. https://doi.org/10.1080/13562517.2014.880687 
Lemke, F., Clark, M., \& Wilson, H. (2011). Customer experience quality: An exploration in business and consumer contexts using repertory grid technique. Journal of the Academy of Marketing Science, 39(6), 846-869. https://doi.org/10.1007/s11747-0100219-0

Lemon, K. N., \& Verhoef, P. C. (2016). Understanding Customer Experience Throughout the Customer Journey. Journal of Marketing, 80(6), 69-96. https://doi.org/10.1509/jm.15.0420

Line, N. D., \& Hanks, L. (2018). The Social Servicescape: A Multidimensional Operationalization. Journal of Hospitality \& Tourism Research, 43(2), 167-187. https://doi.org/10.1177/1096348018767948

Mark, E. (2013). Student satisfaction and the customer focus in higher education. Journal of Higher Education Policy and Management, 35(1), 2-10. https://doi.org/10.1080/1360080X.2012.727703

Miles, M. B., \& Huberman, A. M. (1994). Qualitative data analysis: An expanded sourcebook, 2nd ed. Sage Publications, Inc.

Moore, M. G. (1989). Editorial: Three types of interaction. American Journal of Distance Education, 3(2), 1-7. https://doi.org/10.1080/08923648909526659

Moore, M. L., Capella, M., \& Moore, R. (2005). The impact of customer-to-customer interactions in a high personal contact service setting. Journal of Services Marketing, 19(7), 482-491. https://doi.org/10.1108/08876040510625981

Morgan, M. (2013). Improving the Student Experience: A practical guide for universities and colleges. Routledge.

Neu, W. A. (2012). Unintended Cognitive, Affective, and Behavioral Consequences of Group Assignments. Journal of Marketing Education, 34(1), 67-81. https://doi.org/10.1177/0273475311430806 
Nicholls, R. (2005). Interactions between Service Customers: Managing On-site Customerto-Customer Interactions for Service Advantage: The Poznan University of Economics Publishing House. The Poznan University of Economics Publishing House.

Nicholls, R. (2010). New directions for customer-to-customer interaction research. Journal of Services Marketing, 24(1), 87-97. https://doi.org/10.1108/08876041011017916

Nixon, E., Scullion, R., \& Hearn, R. (2018). Her majesty the student: Marketised higher education and the narcissistic (dis)satisfactions of the student-consumer. Studies in Higher Education, 43(6), 927-943. https://doi.org/10.1080/03075079.2016.1196353

Orlich, D. C., Harder, R. J., Callahan, R. C., Trevisan, M. S., \& Miller, D. Elizabeth. (2013). Teaching strategies: A guide to effective instruction (10th ed.). Wadsworth Cengage Learning; /z-wcorg/.

Pfaff, E., \& Huddleston, P. (2003). Does It Matter if I Hate Teamwork? What Impacts Student Attitudes toward Teamwork. Journal of Marketing Education, 25(1), 37-45. https://doi.org/10.1177/0273475302250571

Ramseook-Munhurrun, P. (2016). A critical incident technique investigation of customers' waiting experiences in service encounters. Journal of Service Theory and Practice, 26(3), 246-272. https://doi.org/10.1108/JSTP-12-2014-0284

Saunders, B., Sim, J., Kingstone, T., Baker, S., Waterfield, J., Bartlam, B., Burroughs, H., \& Jinks, C. (2018). Saturation in qualitative research: Exploring its conceptualization and operationalization. Quality \& Quantity, 52(4), 1893-1907. PubMed. https://doi.org/10.1007/s11135-017-0574-8

Searcy, Y. D. (2017). Let Me Speak to the Manager! Inside Higher Ed.

Sharoff, L. (2008). Critique of the critical incident technique. Journal of Research in Nursing, 13(4), 301-309. https://doi.org/10.1177/1744987107081248 
Sidelinger, R. J., \& Booth-Butterfield, M. (2010). Co-constructing Student Involvement: An Examination of Teacher Confirmation and Student-to-Student Connectedness in the College Classroom. Communication Education, 59(2), 165-184. https://doi.org/10.1080/03634520903390867

Smørvik, K. K., \& Vespestad, M. K. (2020). Bridging marketing and higher education: Resource integration, co-creation and student learning. Journal of Marketing for Higher Education, 30(2), 256-270. https://doi.org/10.1080/08841241.2020.1728465

Söderlund, M. (2011). Other customers in the retail environment and their impact on the customer's evaluations of the retailer. Nordic Retail and Wholesale Conference, 18(3), 174-182. https://doi.org/10.1016/j.jretconser.2010.09.006

Soetanto, D., \& MacDonald, M. (2017). Group work and the change of obstacles over time: The influence of learning style and group composition. Active Learning in Higher Education, 18(2), 99-113. https://doi.org/10.1177/1469787417707613

Staddon, E., \& Standish, P. (2012). Improving the Student Experience. Journal of Philosophy of Education, 46(4), 631-648. https://doi.org/10.1111/j.1467-9752.2012.00885.x

Stangor, C. (2017). Group Processes. Oxford University Press. https://doi.org/10.1093/acrefore/9780190236557.013.255

Stephens Balakrishnan, M., \& Wilkins, S. (2013). Assessing student satisfaction in transnational higher education. International Journal of Educational Management, 27(2), 143-156. https://doi.org/10.1108/09513541311297568

Stodnick, M., \& Rogers, P. (2008). Using SERVQUAL to Measure the Quality of the Classroom Experience. Decision Sciences Journal of Innovative Education, 6(1), 115-133. https://doi.org/10.1111/j.1540-4609.2007.00162.x

Strauss, A. (1985). Work and the Division of Labor. The Sociological Quarterly, 26(1), 1-19. JSTOR. 
Suhre, C. J. M., Jansen, E. P. W. A., \& Harskamp, E. G. (2007). Impact of degree program satisfaction on the persistence of college students. Higher Education, 54(2), 207-226. https://doi.org/10.1007/s10734-005-2376-5

Sultan, P., \& Yin Wong, H. (2013). Antecedents and consequences of service quality in a higher education context: A qualitative research approach. Quality Assurance in Education, 21(1), 70-95. https://doi.org/10.1108/09684881311293070

Swan, K. (2002). Building Learning Communities in Online Courses: The importance of interaction. Education, Communication \& Information, 2(1), 23-49. https://doi.org/10.1080/1463631022000005016

Swanson, S., Frankel, R., \& Sagan, M. (2005). Classroom Encounters: Exploring the Impact of Cultural Differences. Marketing Education Review, 15(3), 37-48. https://doi.org/10.1080/10528008.2005.11488921

Swanson, S. R., \& Davis, J. C. (2000). A View from the Aisle: Classroom Successes, Failures and Recovery Strategies. Marketing Education Review, 10(2), 17-25. https://doi.org/10.1080/10528008.2000.11488704

Swanson, S. R., \& Frankel, R. (2002). A View from the Podium: Classroom Successes, Failures, and Recovery Strategies. Marketing Education Review, 12(2), 25-35. https://doi.org/10.1080/10528008.2002.11488784

Tan, A. H. T., Muskat, B., \& Zehrer, A. (2016). A systematic review of quality of student experience in higher education. International Journal of Quality and Service Sciences, 8(2), 209-228. https://doi.org/10.1108/IJQSS-08-2015-0058

Temple, P., Callender, C., Grove, L., \& Kersh, N. (2014). Managing the Student Experience in a Shifting Higher Education Landscape.

Tombs, A., \& McColl-Kennedy, J. R. (2003). Social-Servicescape Conceptual Model. Marketing Theory, 3(4), 447-475. https://doi.org/10.1177/1470593103040785 
Tomlinson, M. (2017). Student perceptions of themselves as 'consumers' of higher education. British Journal of Sociology of Education, 38(4), 450-467. https://doi.org/10.1080/01425692.2015.1113856

Vianden, J. (2012). The Critical Incident Technique in Student Affairs Research and Practice. Journal of Student Affairs Research and Practice, 49(3), 333-346. https://doi.org/10.1515/jsarp-2012-6441

Vianden, J., \& Yakaboski, T. (2017). Critical incidents of student satisfaction at German universities. International Journal of Educational Management, 31(7), 944-957. https://doi.org/10.1108/IJEM-06-2015-0071

Vos, L., \& Page, S. (2019). MARKETIZATION, PERFORMATIVE ENVIRONMENTS AND THE IMPACT OF ORGANISATIONAL CLIMATE ON TEACHING PRACTICE IN BUSINESS SCHOOLS. Academy of Management Learning \& Education. https://doi.org/10.5465/amle.2018.0173

Voss, R. (2009). Studying critical classroom encounters: The experiences of students in German college education. Quality Assurance in Education, 17(2), 156-173. https://doi.org/10.1108/09684880910951372

Voss, R., Gruber, T., \& Reppel, A. (2010). Which classroom service encounters make students happy or unhappy?: Insights from an online CIT study. International Journal of Educational Management, 24(7), 615-636. https://doi.org/10.1108/09513541011080002

Walker, J. (2015). Using Critical Incidents to Understand ESL Student Satisfaction. TESL Canada Journal, 32(2), 95. https://doi.org/10.18806/tesl.v32i2.1210

Weaver, R. R., \& Qi, J. (2005). Classroom Organization and Participation: College Students' Perceptions. The Journal of Higher Education, 76(5), 570-601. https://doi.org/10.1080/00221546.2005.11772299 
Weerasinghe, I. S., Lalitha, R., \& Fernando, S. (2017). Students' Satisfaction in Higher Education Literature Review. American Journal of Educational Research, 5(5), 533539. https://doi.org/10.12691/education-5-5-9

Williams, E. A., Duray, R., \& Reddy, V. (2006). Teamwork Orientation, Group Cohesiveness, and Student Learning: A Study of the Use of Teams in Online Distance Education. Journal of Management Education, 30(4), 592-616. https://doi.org/10.1177/1052562905276740

Woodall, T., Hiller, A., \& Resnick, S. (2014). Making sense of higher education: Students as consumers and the value of the university experience. Studies in Higher Education, 39(1), 48-67. https://doi.org/10.1080/03075079.2011.648373

Zeithaml, V., Bitner, M. J., \& Gremler, D. (2017). Services Marketing: Integrating Customer Focus Across the Firm (7th ed.). McGraw-Hill. 
Figure 1

Critical incidents caused by other students.

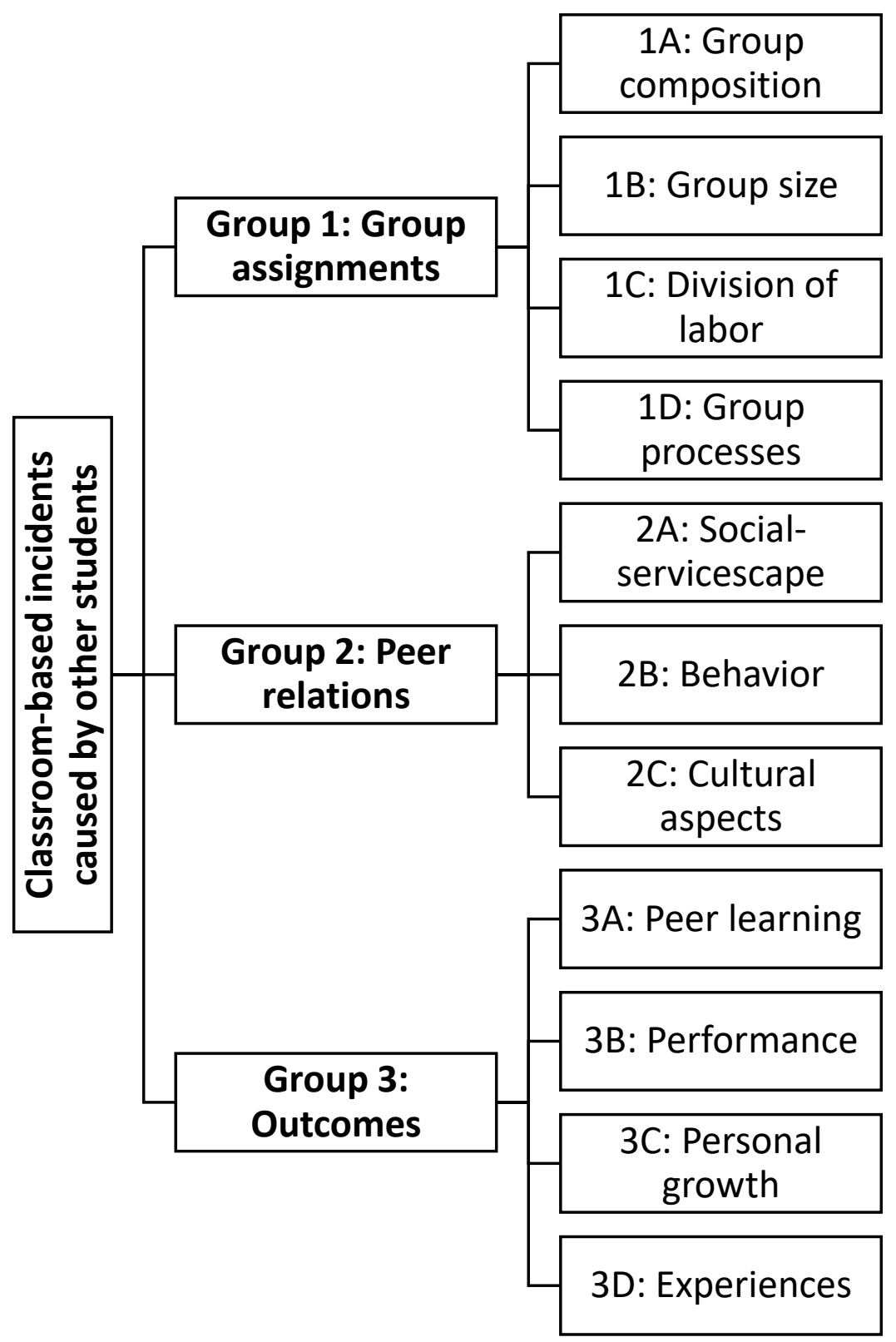




\section{Table 1}

Numeric tallies of other students' critical incidents.

\begin{tabular}{|l|c|c|c|c|c|c|}
\hline Group and category & $\begin{array}{c}\text { Satisfactory } \\
\text { No. }\end{array}$ & $\begin{array}{c}\text { Satisfactory } \\
\mathbf{\%}\end{array}$ & $\begin{array}{c}\text { Dissatisfactory } \\
\text { No. }\end{array}$ & $\begin{array}{c}\text { Dissatisfactory } \\
\mathbf{\%}\end{array}$ & $\begin{array}{c}\text { Total } \\
\text { No. }\end{array}$ & $\begin{array}{c}\text { Total } \\
\mathbf{\%}\end{array}$ \\
\hline $\begin{array}{l}\text { Group } \mathbf{1 .} \text { Group } \\
\text { assignments }\end{array}$ & & & & & & \\
A: Group composition & 12 & 2.8 & 11 & 2.6 & 23 & 2.7 \\
B: Group size & - & - & 3 & 0.7 & 3 & 0.7 \\
C: Division of labor & 18 & 4.3 & 112 & 26.6 & 130 & 15.4 \\
D: Group processes & 64 & 15.2 & 30 & 7.1 & 94 & 11.1 \\
\hline Group 1. Subtotal & $\mathbf{9 4}$ & $\mathbf{2 2 . 3}$ & $\mathbf{1 5 6}$ & $\mathbf{3 7 . 0}$ & $\mathbf{2 5 0}$ & $\mathbf{2 9 . 8}$ \\
\hline Group 2. Peer relations & & & & & & \\
A: Social-servicescape & 49 & 11.6 & 69 & 16.4 & 118 & 14.0 \\
B: Behavior & 87 & 20.6 & 100 & 23.7 & 187 & 22.1 \\
C: Cultural aspects & 14 & 3.3 & 15 & 3.5 & 29 & 3.4 \\
& & & & & & \\
\hline Group 2. Subtotal & $\mathbf{1 5 0}$ & $\mathbf{3 5 . 5}$ & $\mathbf{1 8 4}$ & $\mathbf{4 3 . 6}$ & $\mathbf{3 3 4}$ & $\mathbf{3 9 . 5}$ \\
\hline Group 3. Outcomes & & & & & & \\
A: Peer learning & 68 & 16.1 & 13 & 3.1 & 81 & 9.6 \\
B: Performance & 24 & 5.7 & 53 & 12.5 & 77 & 9.1 \\
C: Personal growth & 19 & 4.5 & 5 & 1.2 & 24 & 2.8 \\
D: Experiences & 67 & 15.9 & 11 & 2.6 & 78 & 9.2 \\
\hline Group 3. Subtotal & $\mathbf{1 7 8}$ & $\mathbf{4 2 . 2}$ & $\mathbf{8 2}$ & $\mathbf{1 9 . 4}$ & $\mathbf{2 6 0}$ & $\mathbf{3 0 . 7}$ \\
\hline Column total & $\mathbf{4 2 2}$ & $\mathbf{1 0 0}$ & $\mathbf{4 2 2}$ & $\mathbf{1 0 0}$ & $\mathbf{8 4 4}$ & $\mathbf{1 0 0}$ \\
\hline
\end{tabular}




\section{Table 2}

Group Assignments: Sample satisfying and dissatisfying critical incidents.

\begin{tabular}{|l|l|}
\hline Type of incident & Sample incident \\
\cline { 1 - 2 } Satisfying incidents & \multicolumn{1}{|l|}{ "Felt comfortable because we could choose groups so I was with } \\
1A. Group composition \\
it quickly."
\end{tabular}




\section{Table 3}

Peer Relations: Sample satisfying and dissatisfying critical incidents.

\begin{tabular}{|c|c|}
\hline \multirow{2}{*}{$\begin{array}{l}\text { Type of incident } \\
\text { Satisfying incidents }\end{array}$} & Sample incident \\
\hline & \multirow[b]{2}{*}{$\begin{array}{l}\text { "Everyone was encouraged to state their own opinion, which } \\
\text { helped to recognize different points of view." } \\
\text { "Thanks to other students I was less stressed when presenting in } \\
\text { other language." }\end{array}$} \\
\hline 2A. Social-servicescape & \\
\hline 2B. Behavior & $\begin{array}{l}\text { "There have been few times throughout my study, that working } \\
\text { with other students had really helped me. Sometimes, I may have } \\
\text { given up on the assignment, if I hadn't been working with my } \\
\text { friends." } \\
\text { "This year we became very supportive. Because we worked } \\
\text { together on projects, we started to respect each other more, help } \\
\text { each other, and listen to each other." }\end{array}$ \\
\hline 2C. Cultural aspects & $\begin{array}{l}\text { "Students from different cultures were interesting and always } \\
\text { brought something new." } \\
\text { "Working with students from other countries and cultures for me } \\
\text { is interesting as I have opportunity to discover lots of new } \\
\text { information or find out the truth about what I knew from media } \\
\text { about it." }\end{array}$ \\
\hline Dissatisfying incidents & \multirow[b]{2}{*}{$\begin{array}{l}\text { "Some people made fun of me. It's stressful and makes me feel } \\
\text { ashamed talking in the class." } \\
\text { "People in the classroom told me that we compete for the same } \\
\text { jobs in the future" }\end{array}$} \\
\hline $\begin{array}{l}\text { 2A. Social- } \\
\text { Servicescape }\end{array}$ & \\
\hline 2B. Behavior & $\begin{array}{l}\text { "Some people did not want to help, share notes, or reveal } \\
\text { information." } \\
\text { "Before an exam I've asked few people to explain me how to solve } \\
\text { the task. They said they don't know how to but they know it will } \\
\text { not be on the exam. Guess what? It was there and they knew how } \\
\text { to solve it." }\end{array}$ \\
\hline 2C. Cultural aspects & $\begin{array}{l}\text { "Some of the students from Ukraine were speaking Russian } \\
\text { which Polish students did not understand." }\end{array}$ \\
\hline
\end{tabular}




\section{Table 4}

Outcomes and results: Sample satisfying and dissatisfying critical incidents.

\begin{tabular}{|c|c|}
\hline Type of incident & Sample incident \\
\hline Satisfying incidents & \multirow[b]{2}{*}{$\begin{array}{l}\text { "Participating in a high-quality debate is very beneficial for all } \\
\text { parties, provided that they are prepared for it academically and } \\
\text { have something to say/to contribute. A very nice to exchange } \\
\text { ideas and find the solutions for the problems." } \\
\text { "I particularly like to cooperate with students older than I am. } \\
\text { Thanks to that it's possible to imitate them, and the way they work. } \\
\text { They are more experienced, easier to communicate and more } \\
\text { trustworthy." } \\
\text { "One of the biggest advantages of working with other students } \\
\text { was a chance of knowing other people's ideas. Each member of } \\
\text { our group had something original that he/she contributed. Some } \\
\text { people thought about ideas that I couldn't have on my own." }\end{array}$} \\
\hline 3A. Peer learning & \\
\hline 3B. Performance & $\begin{array}{l}\text { "Other student (project together) presented my work so good that } \\
\text { it impressed both teacher and the group." }\end{array}$ \\
\hline 3C. Personal growth & "In classroom I found out about business that own now". \\
\hline 3D. Experiences & $\begin{array}{l}\text { "First day I met some new students and even though we are not } \\
\text { in same classes we are still friends today." }\end{array}$ \\
\hline Dissatisfying inciden & \\
\hline 3A. Peer learning & $\begin{array}{l}\text { "One student [was] disputing teacher all the time, I couldn't } \\
\text { focus and didn't understand whole lecture correctly." } \\
\text { "I worked with people who knew much less than I did and I didn't } \\
\text { learn anything new." }\end{array}$ \\
\hline 3B. Performance & $\begin{array}{l}\text { "One person can drastically affect the group either positively or } \\
\text { negatively. My ideas were completely ignored. Other student did } \\
\text { everything his way and it affected our final score." }\end{array}$ \\
\hline 3C. Personal growth & $\begin{array}{l}\text { "Other student were too active so I couldn't present my point of } \\
\text { view." }\end{array}$ \\
\hline 3D. Experiences & $\begin{array}{l}\text { "Some people don't want to integrate and it often put me in a } \\
\text { bad mood" }\end{array}$ \\
\hline
\end{tabular}




\section{Appendix: Survey Questionnaire}

1. First, we would like to ask you to recall a classroom-based, student-to-student interaction experience that left you particularly SATISFIED.

2. Can you describe in detail why you were satisfied with this particular student-tostudent interaction experience? Were there any other factors that caused you to be satisfied? If so, please elaborate.

3. Now, we would like to ask you to recall a classroom-based, student-to-student interaction experience that left you particularly DISSATISFIED.

4. Can you describe in detail why you were dissatisfied with this particular student-tostudent interaction experience? Were there any other factors that caused you to be dissatisfied? If so, please elaborate. 